\title{
Mechanisms of NO-Resistant Relaxation Induced by Acetylcholine in Rabbit Renal Arteries
}

\author{
Seong-Chun KWON \\ Department of Physiology, College of Medicine, Yonsei University, Seoul 120-752, Korea
}

(Received 28 August 2000/Accepted 12 September 2000)

ABSTRACT. The effects of $\mathrm{K}^{+}$channel blockers and $\mathrm{P}_{2 \mathrm{Y}}$ receptor agonist/antagonist on the vasorelaxation mediated by endothelium-derived hyperpolarizing factor (EDHF) were investigated in the rabbit renal artery. Acetylcholine (ACh, $1 \mathrm{nM}-10 \mu \mathrm{M}$ ) induced endotheliumdependent relaxation of arterial rings precontracted with norepinephrine $(\mathrm{NE}, 1 \mu \mathrm{M})$ in a concentration-dependent manner. $\mathrm{N}^{\mathrm{G}}$-nitro-Larginine (L-NAME, $0.1 \mathrm{mM}$ ), an inhibitor of NO synthase, partially inhibited the ACh-induced endothelium-dependent relaxation. The ACh-induced relaxation was only partially inhibited by L-NAME whereas combined addition of L-NAME and $30 \mathrm{mM} \mathrm{KCl} \mathrm{completely}$ inhibited the relaxation. The ACh-induced relaxation observed in the presence of L-NAME was significantly reduced by a combination of iberiotoxin $(0.1 \mu \mathrm{M})$ and apamin $(1 \mu \mathrm{M})$, and almost completely blocked by 4-aminopyridine $(5 \mathrm{mM})$. The ACh-induced relaxation was antagonized by $\mathrm{P}_{2 \mathrm{Y}}$ receptor antagonist, cibacron blue $(10$ and $100 \mu \mathrm{M})$ in a concentration-dependent manner. Furthermore, $\mathrm{ADP}_{\beta} \mathrm{S}$, a potent $\mathrm{P}_{2 \mathrm{Y}}$ agonist, induced the endothelium-dependent relaxation, and this relaxation was markedly reduced by either the combination of iberiotoxin and apamin or by cibacron blue alone. In conclusion, ACh may activate the release of ATP from endothelial cells which in turn activates a $\mathrm{P}_{2 \mathrm{Y}}$ receptor on the endothelial cells followed by a release of EDHF, resulting in a vasorelaxation via a mechanism that involves activation of both the voltage-gated $\mathrm{K}^{+}$channels and the $\mathrm{Ca}^{2+}$-activated $\mathrm{K}^{+}$channels. KEY WORDS: ATP, $\mathrm{K}^{+}$channel, rabbit renal artery.

J. Vet. Med. Sci. 63(1): 37-40, 2001

The vascular endothelial cells play an important role in maintaining the vascular homeostasis by liberating several vasodilator substances, including nitric oxide (NO), prostacyclin $\left(\mathrm{PGI}_{2}\right)$, and endothelium-derived hyperpolarizing factor (EDHF) [1]. EDHF is released by an increase in the $\mathrm{Ca}^{2+}$ concentration within endothelial cells caused by agonists including acetylcholine (ACh), bradykinin, and ATP [7, 10]. EDHF activates $\mathrm{K}^{+}$channels of smooth muscle cells, hyperpolarizes the cell membrane and thus causes the relaxation of smooth muscle [2]. There are several types of $\mathrm{K}^{+}$channels in vascular smooth muscle cells, and studies with various $\mathrm{K}^{+}$ channel blockers have led to controversial conclusions on the identity of the $\mathrm{K}^{+}$channels involved in the EDHF-dependent vasorelaxation [8].

As it is generally accepted that the $\mathrm{P}_{2 \mathrm{Y}}$ purinoceptors are located in vascular endothelial cells, the $\mathrm{P}_{2 \mathrm{Y}}$-mediated relaxation is an endothelium dependent phenomenon [13]. Recent studies suggest that activation of the $\mathrm{P}_{2 \mathrm{Y}}$ receptors induces endothelium-dependent vasodilation mediated by EDHF [10, $14,15,18]$. In the rat mesenteric artery, $P_{2 Y}$ receptor-induced vasodilatation is antagonized by a combination of the $\mathrm{K}^{+}$ channels inhibitors, charybdotoxin and apamin, which prevents hyperpolarization and relaxation mediated by EDHF in different blood vessels $[3,9,20]$. However, no study has provided direct evidence supporting that EDHF is released by activation of the endothelial $\mathrm{P}_{2 \mathrm{Y}}$ receptors.

The aims of this study were to pharmacologically determine (a) whether EDHF contributes to endothelium-dependent vasorelaxation in the rabbit renal artery, and (b) the effects of $\mathrm{K}^{+}$channel blockers and $\mathrm{P}_{2 \mathrm{Y}}$ receptor angonist on the ACh-induced relaxation in order to characterize the mechanism of action of ACh. The effect of a potent $\mathrm{P}_{2 \mathrm{Y}}$ ago- nist, $\mathrm{ADP}_{\beta} \mathrm{S}$, on NE-contracted tissues was also investigated and the results were compared with that of $\mathrm{ACh}$-induced relaxation.

\section{MATERIALS AND METHODS}

Preparation of artery rings: New Zealand white rabbits $(2-3 \mathrm{~kg})$ of either sex were killed by exsanguination after anaesthesia with sodium pentobarbital (30 mg/kg iv). The renal artery was quickly excised and placed in a cold physiological salt solution (PSS) of the following composition (in $\mathrm{mM}$ ): $\mathrm{NaCl} 136.9, \mathrm{KCl} 5.4, \mathrm{CaCl}_{2}$ 1.5, $\mathrm{MgCl}_{2}$ 1.2, $\mathrm{NaHCO}_{3}$ 23.8, EDTA 0.01, glucose 5.5. The $\mathrm{pH}$ of the solution after saturation with $95 \% \mathrm{O}_{2}+5 \% \mathrm{CO}_{2}$ gas mixture was 7.4. The vessels were cut into $1 \mathrm{~mm}$-wide ring segments and were placed in $20 \mathrm{ml}$ tissue baths between two L-shaped hooks, one of which was attached to a force transducer for isometric measurement. The tissue baths were thermostatically kept at $37^{\circ} \mathrm{C}$. A resting tension of $0.5 \mathrm{~g}$ was maintained throughout the experiments.

After a 90 min equilibration, tissues contracted by NE (1 $\mu \mathrm{M})$. When stable contractions were obtained, ACh was added cumulatively to determine the concentration-response relationship. The function of the endothelium was examined at the beginning of each experiment by observing the effects of $\mathrm{ACh}(1 \mu \mathrm{M})$ to induce relaxation. In some experiments, endothelium was mechanically removed by gentle rubbing with moistened cotton, functional removed of endothelium was confirmed by the lack of a relaxant response to ACh (1 $\mu \mathrm{M})$. Unless otherwise stated, L-NAME $(0.1 \mathrm{mM})$ was added to the PSS.

Chemicals: The chemicals used were acetylcholine, 
$\mathrm{ADP}_{\beta} \mathrm{S}$, 4-aminopyridine (4-AP), apamin, cibacron blue, iberiotoxin, indomethacin, $\mathrm{N}^{\mathrm{G}}$-nitro-L-arginine (L-NAME), and norepinephrine (Sigma Chemical).

Statistics: The results of the experiments are expressed as mean \pm S.E.M and the number of preparations taken from separate animals was indicated by $n$. Statistical significance was examined by Student's paired or unpaired $t$ test and $P$ values less than 0.05 were considered significant.

\section{RESULTS}

In the endothelium-intact rabbit renal artery rings precontracted with NE $(1 \mu \mathrm{M})$, ACh $(1 \mathrm{nM}-10 \mu \mathrm{M})$ elicited a concentration-dependent relaxation (Fig. 1). The ACh-induced vasorelaxation was completely abolished by mechanical removal of endothelium $(n=8)$. The relaxant response was markedly reduced by the NOS inhibitor, L-NAME $(0.1 \mathrm{mM})$. In arteries contracted with $30 \mathrm{mM} \mathrm{KCl}$ plus $1 \mu \mathrm{M} \mathrm{NE}$ in the presence of $0.1 \mathrm{mM}$ L-NAME, ACh did not induce relaxation, suggesting that the relaxation was mediated by both the release of NO and an endothelium-dependent hyperpolarization.

The contribution of $\mathrm{K}^{+}$channels to the $\mathrm{ACh}$-induced relaxation was assessed in a renal artery in the presence of $\mathrm{L}$ NAME $(0.1 \mathrm{mM})$. The ACh-induced relaxation was almost completely abolished by an inhibitor of the delayed rectifier $\mathrm{K}^{+}$channels, 4-AP (5 mM) (Fig. 2). The ACh-induced relaxation was also strongly inhibited by an inhibitor of the large conductance $\mathrm{Ca}^{2+}$-activated $\mathrm{K}^{+}$channels, iberiotoxin $(0.1$ $\mu \mathrm{M})$ (Fig. 2), and further reduced by the combination of iberiotoxin $(0.1 \mu \mathrm{M})$ plus apamin $(1 \mu \mathrm{M})($ Fig. 2$)$. On the other hand, an inhibitor of the ATP-sensitive $\mathrm{K}^{+}$channels, glibenclamide $(10 \mu \mathrm{M})$, did not affect the ACh-induced relaxation ( $\mathrm{n}=5$, data not shown).

The possible involvement of the $\mathrm{P}_{2 \mathrm{Y}}$ purinoceptor to AChinduced relaxation was assessed with cibacron blue, a $P_{2 Y}$ receptor antagonist, in the rabbit renal artery pretreated with L-NAME $(0.1 \mathrm{mM})$. The ACh-induced relaxation was significantly reduced by a cibacron blue $(10$ and $100 \mu \mathrm{M})$ in a concentration-dependent manner (Fig. 3).

In the endothelium-intact ring segments precontracted with $\mathrm{NE}(1 \mu \mathrm{M}), \mathrm{ADP}_{\beta} \mathrm{S}$ also produced concentration-dependent relaxations. The relaxant response was markedly reduced either by the combination of iberiotoxin $(0.1 \mu \mathrm{M})$ plus apamin $(1 \mu \mathrm{M})$ or by cibacron blue $(100 \mu \mathrm{M})$ (Fig. 4). The $\mathrm{ADP}_{\beta} \mathrm{S}$-induced vasorelaxation was completely abolished by the mechanical removal of endothelium $(n=6)$.

\section{DISCUSSION}

The muscarinic agonist, ACh, produced endotheliumdependent relaxations in the segments of rabbit renal arteries contracted with NE. Inhibition of NO release with L-NAME reduced but did not abolished the ACh-induced relaxation. These results indicate that the endothelium-dependent relaxant response to $\mathrm{ACh}$ in the rabbit renal artery is mediated by at least two different factors, namely NO and EDHF. More-

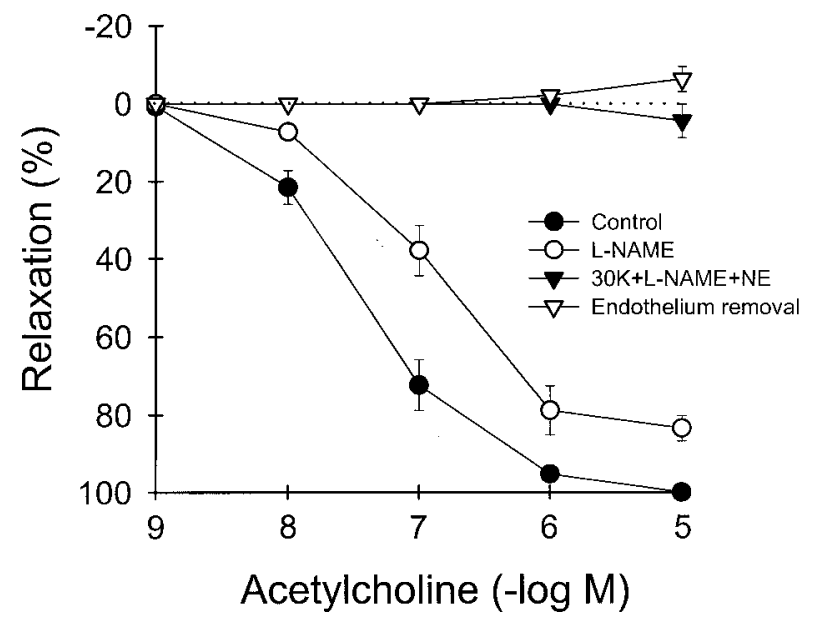

Fig. 1. Average concentration-response curves for the relaxant effects of ACh in the absence (O) and presence of L-NAME (100 $\mu \mathrm{M}$,) or L-NAME plus $30 \mathrm{mM} \mathrm{KCl}(\boldsymbol{\nabla})$ in the rabbit renal artery precontracted by NE $(1 \mu \mathrm{M})$. $(\nabla)$ Endothelium was removed. Responses are expressed as percentage of contraction elicited by $\mathrm{NE}(1 \mu \mathrm{M})$ before the addition of ACh. Each point represents mean of 6-10 rings and S.E.M. is shown by vertical bar.

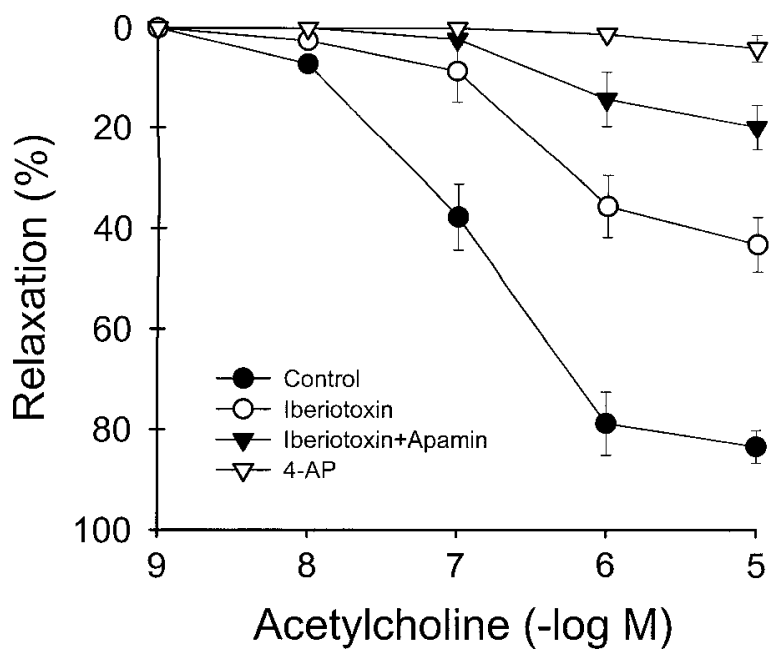

Fig. 2. Effects of $\mathrm{K}^{+}$channel blockers on ACh-induced relaxation in the endothelium-intact, L-NAME $(0.1 \mathrm{mM})$-pretreated segments of the rabbit renal artery precontracted with NE $(1 \mu \mathrm{M})$. Control; $\bigcirc$, in the presence of iberiotoxin $(0.1 \mu \mathrm{M})$; $\boldsymbol{\nabla}$, in the presence of iberiotoxin $(0.1 \mu \mathrm{M})$ and apamin $(1 \mu \mathrm{M}) ; \nabla$, in the presence of 4-AP $(5 \mathrm{mM})$. Responses are expressed as the percentage of contraction elicited by NE before the addition of ACh. Each point represents mean of 5-8 rings and S.E.M. is shown by vertical bar.

over, the ACh-induced relaxation was completely prevented by L-NAME in the presence of high extracellular $\mathrm{K}^{+}$, suggesting that EDHF is released from endothelial cells and contributes to the endothelium-dependent relaxation. Similar observations have been made with the rabbit carotid artery 


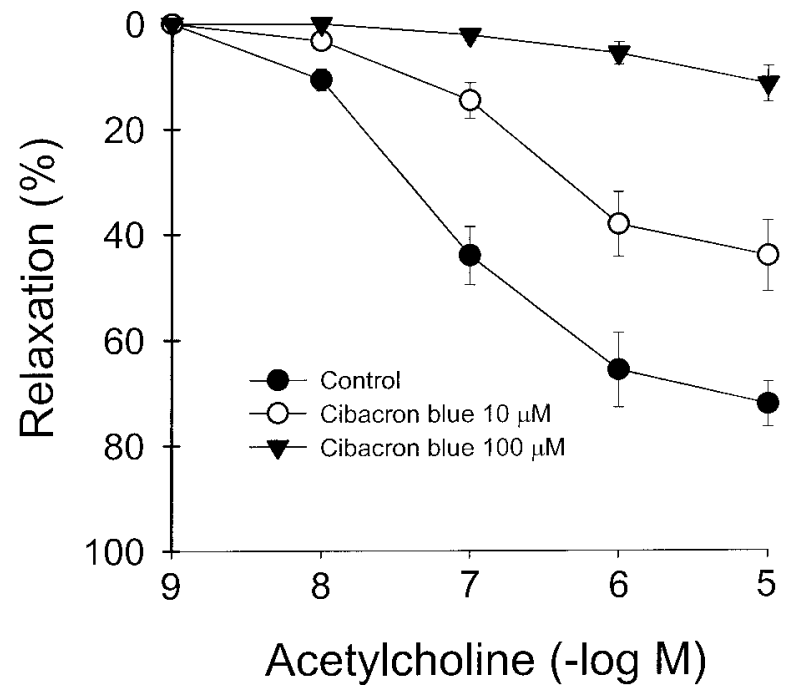

Fig. 3. Effects of $\mathrm{P}_{2 \mathrm{Y}}$ purinoceptor antagonist, cibacron blue, on ACh-induced relaxation in the endothelium-intact, L-NAME $(0.1$ $\mathrm{mM})$-pretreated rabbit renal artery precontracted with NE $(1 \mu \mathrm{M})$. - Control; $\bigcirc$, in the presence of $10 \mu \mathrm{M}$ cibacron blue; $\boldsymbol{\nabla}$, in the presence of $100 \mu \mathrm{M}$ cibacron blue. Responses are expressed as percentage of the contraction elicited by NE before the addition of ACh. Each point represents mean of 6 rings and S.E.M. is shown by vertical bar.

and the rat renal artery $[4,7]$.

The cellular mechanism(s) underlying the EDHF-mediated smooth muscle relaxation has not been fully elucidated, especially with respect to the subtype of $\mathrm{K}^{+}$channels. In the present study, ACh-induced relaxation was abolished by 4$\mathrm{AP}$, a specific inhibitor of delayed rectifier $\mathrm{K}^{+}(\mathrm{Kv})$ channels, suggesting that $\mathrm{Kv}$ channels are involved in the ACh-mediated relaxation of the rabbit renal artery. The EDHF-mediated relaxation in the rat hepatic artery has been shown to be inhibited by $4-A P$ and charybdotoxin $[19,20]$. Since charybdotoxin inhibits not only $\mathrm{Ca}^{2+}$-activated $\mathrm{K}^{+}$channels $\left(\mathrm{BK}_{\mathrm{Ca}}\right)$, but also $\mathrm{Kv}$ channels, this leads to the conclusion that the $\mathrm{Kv}$ channels are a target for EDHF. Iberiotoxin, the selective inhibitor of $\mathrm{BK}_{\mathrm{Ca}}$ channels, also significantly reduced $\mathrm{ACh}-$ induced relaxation, suggesting that the $\mathrm{BK}_{\mathrm{Ca}}$ channels also play a role in the ACh-induced relaxation. Application of apamin in the presence of iberiotoxin further inhibited the $\mathrm{ACh}$-induced relaxation, suggesting that small conductance $\mathrm{Ca}^{2+}$ channel $\left(\mathrm{SK}_{\mathrm{Ca}}\right)$ channel is also involved in the AChinduced relaxation [1]. Taken together, these data clearly indicate that in the rabbit renal artery, both the $\mathrm{Kv}$ and $\mathrm{BK}_{\mathrm{Ca}}$ are involved in the ACh-mediated, NO-resistant relaxation.

In the present study, the ACh-induced relaxation was inhibited by an antagonist of purinoceptor, cibacron blue, in a concentration-dependent manner. These results indicate that the response may be evoked by the activation of the $\mathrm{P}_{2 \mathrm{Y}}$ purinoceptors. The significant inhibition of the AChinduced relaxation is likely to be due to a specific action,

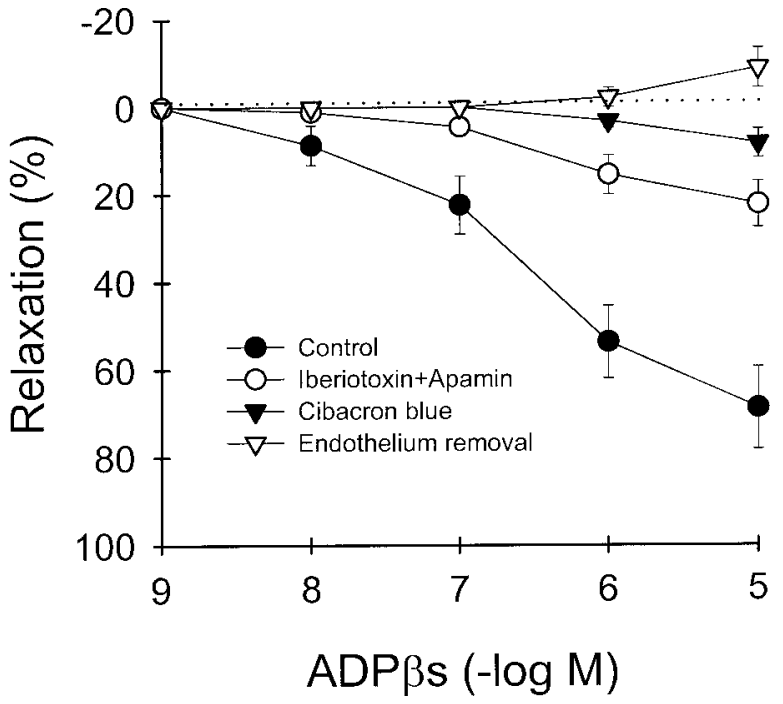

Fig. 4. Average concentration-response curves for the relaxant effects of $\mathrm{ADP}_{\beta} \mathrm{S}$, a potent $\mathrm{P}_{2 \mathrm{Y}}$ agonist, in the endothelium-intact rabbit renal artery precontracted with $\mathrm{NE}(1 \mu \mathrm{M})$. Control; $\bigcirc$, in the presence of iberiotoxin $(1 \mu \mathrm{M})$ plus apamin $(1 \mu \mathrm{M}) ; \boldsymbol{\nabla}$, in the presence of $100 \mu \mathrm{M}$ cibacron blue. $(\nabla)$ Endothelium was removed. Responses are expressed as percentage of the contraction elicited by NE before the addition of ACh. Each point represents mean of 5-6 rings and S.E.M. is shown by vertical bar.

because cibacron blue has been demonstrated to be a selective $\mathrm{P}_{2 \mathrm{Y}}$ receptor antagonist in vascular smooth muscles [6]. A number of studies reported that the $\mathrm{P}_{2 \mathrm{Y}}$ purinoceptors are typically located on the endothelial cells, and the activation of endothelial $P_{2 Y}$ induced the release of $\operatorname{EDHF}[10,12,13]$. Vasoactive substances such as noradrenaline, bradykinin, $\mathrm{ACh}$ and serotonin are known to release ATP from endothelial cells $[16,17]$. These results indicated that ATP derived from endothelial cells activates the $\mathrm{P}_{2 Y}$ purinoceptors on the endothelial cells to induce the EDHF mediated responses.

In the present study, the selective $\mathrm{P}_{2 \mathrm{Y}}$ receptor agonist, $\mathrm{ADP}_{\beta} \mathrm{S}$, induced relaxation of the NE-precontracted rabbit renal artery as ACh did. This relaxation may be due to activation of $\mathrm{P}_{2 Y}$ purinoceptors located on endothelial cells with subsequent release of EDHF, since the vasorelaxation induced by $\mathrm{ADP}_{\beta} \mathrm{S}$ was antagonized by iberiotoxin plus apamin, cibacron blue or by endothelial denudation. Similarly, in rat mesenteric arteries, it has been reported that stimulation of the $\mathrm{P}_{2 \mathrm{Y}}$ receptors triggers endothelium-dependent relaxation, which was inhibited by the combination of iberiotoxin and apamin in the presence of L-NOARG and indomethacin [9]. Recent studies also suggests that activation of the $\mathrm{P}_{2 Y}$ receptors induces endothelium-dependent vasodilation mediated by EDHF [10, 11, 14, 15, 18]. Therefore, it is suggested that $\mathrm{ADP}_{\beta} \mathrm{S}$ activates the $\mathrm{P}_{2 \mathrm{Y}}$ receptors to release EDHF from endothelial cells of the rabbit renal arteries. 


\section{REFERENCES}

1. Adeagbo, A.S.O. and Triggle, C.R. 1993. Varying extracellular $\left[\mathrm{K}^{+}\right]$: a functional approach to separating EDHF- and EDNOrelated mechanisms in perfused rat mesenteric arterial bed. $J$. Cardiovasc. Pharmacol. 21: 423-429.

2. Cohen, R.A. and Vanhoutte, P.M. 1995. Endothelium-dependent hyperpolarization: beyond nitric oxide and cyclic GMP. Circulation 92: 3337-3349.

3. Corriu, C., Feletou, M., Canet, E. and Vanhoutte, P.M. 1996. Endothelium-derived factors and hyperpolarization of the carotid artery of the guinea-pig. Br. J. Pharmacol. 119: 959964.

4. Dong, H., Waldron, G.J., Galipeau, D., Cole, W.C. and Triggle, C.R. 1997. NO/PGI2-independent vasorelaxation and the cytochrome $\mathrm{P} 450$ pathway in rabbit carotid artery. Br. J. Pharmacol. 120: 695-701.

5. Feletou, M. and Vanhoutte, P.M. 1988. Endothelium-dependent hyperpolarization of canine coronary artery smoth muscle. $\mathrm{Br} . \mathrm{J}$. Pharmacol. 93: 515-524.

6. Hopwood, A.M. and Burnstock, G. 1987. ATP mediates coronary vasoconstiction via $\mathrm{P} 2 \mathrm{x}$-urinoceptors and coronary vasodilation via $\mathrm{P} 2 \mathrm{y}$-purinoceptors in the isolated perfused rat heart. Eur. J. Pharmacol. 136: 49-54.

7. Jiang, F., Li, C.C. and Rand, M.J. 2000. Mechanisms of nitric oxide-independent relaxations induced by carbachol and acetylcholine in rat isolated renal artery. Br. J. Pharmacol. 130: 11911200

8. Kuriyama, H., Kitamura, K. and Nabata, H. 1995. Pharmacological and physiological significance of ion channels and factors that modulate them in vascular tissues. Pharmacol. Rev. 47: 387-573.

9. Malmsjo, M., Edvinson, L. and Erlinge, D. 1998. P2U-receptor mediated endothelium-dependnet but nitric oxide independent vascular relaxation. Br. J. Pharmacol. 123: 719-729.

10. Malmsjo, M., Erlinge, D., Hogestatt, E.D. and Zygmunt, P.M. 1999. Endothelial P2Y receptors induce hyperpolarization of vascular smooth muscle by release of endothelium-derived hyperpolarizing factor. Eur. J. Pharmacol. 364: 169-173.

11. McMurray, G., Dass, N. and Brading, A.F. 1998. Purinoceptor subtypes mediating contraction and relaxation of marmoset urinary bladder smooth muscle. Br. J. Pharmacol. 123: 15791586.

12. O'Connor, S.E., Dainty, I.A. and Left, P. 1991. Further subclassification of ATP receptors based on agonist studies. Trends in Pharmacol. Sci. 12: 137-141.

13. Olsson, R.A. and Pearson, J.D. 1990. Cardiovascular purinoceptors. Physiol. Rev. 70: 761-845.

14. Ralevic, V. and Burnstock, G. 1991. Effects of purins and pyrimidines on the rat mesenteric arterial bed. Circulation Res. 69: $1583-1590$

15. Saiag, B., Hillaire-Buys, D., Chapal, P., Pape, B., Allain, H. and Loubatieres-Mariani, M.M. 1996. Study of the mechanisms involved in adenosine-5-O-(2-thiodiphosphate) induced relaxation of the thoracic aorta and pancreatic vascular bed. $B r . J$. Pharmacol. 118: 804-810.

16. Shinozuka, K., Hashimoto, M., Masumura, S., Bjur, R.A. Westfall, D.P. and Hattori, K. 1994. In vitro studies of release of adenine nucleotides and adenosine from rat vascular endothelium in response to 1-adrenoceptor stimulation. Br. J. Pharmacol. 113: 1203-1208.

17. Yang, S.Y., Cheek, D.J., Westfall, D.P. and Buxton, I.L.O. 1994. Purinergic axis in cardiac blood vessels: Agonist-mediated release of ATP from cardiac endothelial cells. Circ. Res. 74: 401-407.

18. You, J., Johnson, T.D., Childres, W.F. and Bryan, R.M. 1997. Endothelial-mediated dilatations of rat middle cerebral arteries by ATP and ADP. Am. J. Physiol. 273: H1472-H1477.

19. Zygmunt, P.M., Edwards, G., Weston, A.H., Larsson, B. and Hogestatt, E.D. 1997. Involvement of voltage-dependent potassium channels in the EDHF-mediated relaxation of rat hepatic artery. Br. J. Pharmacol. 121: 141-149.

20. Zygmunt, P.M. and Hogestatt, E.D. 1996. Role of potassium channels in endothelium-dependent relaxation resistant to nitroarginine in the rat hepatic artery. Br. J. Pharmacol. 117: 1600-1606. 